\title{
Epidemiological and Psychosocial Profile of Juvenile Delinquency: Case Study of Delinquent Children and Adolescents under Court Order in Benin (2015)
}

\begin{abstract}
Anselme Djidonou ${ }^{1 *}$, Francis Tognon Tchégnonsi ${ }^{1}$, Jean-Marie Adovoékpé ${ }^{1}$, Iréti Nethania Elie Ataïgba1, Amadou Soulémane Kpakatia1, Emilie Fiossi-Kpadonou2, Prosper Gandaho' ${ }^{1}$, Josiane Houngbé-Ezin²
\end{abstract}

${ }^{1}$ Faculty of Medicine, University of Parakou, Parakou, Benin

${ }^{2}$ Faculty of Health Sciences, University of Abomey-Calavi, Abomey-Calavi, Benin

Email: "cmpjubile2000@gmail.com

Received 21 January 2016; accepted 15 February 2016; published 18 February 2016

Copyright (C) 2016 by authors and Scientific Research Publishing Inc.

This work is licensed under the Creative Commons Attribution International License (CC BY).

http://creativecommons.org/licenses/by/4.0/

(c) (i) Open Access

\begin{abstract}
Background: Given the scale of juvenile delinquency in Benin, families, judicial bodies and the society seemed overwhelmed. The objective was to study the epidemiological and psychosocial profile of delinquent children and adolescents under court order (DCAUCO) in Benin civil prisons in 2015. Methods of study: It was a descriptive and cross-sectional study which involved 117 children aged 11 to 18 years, recruited from $6^{\text {th }}$ May to $10^{\text {th }}$ September 2015 in nine Civil Prisons and a Child and Adolescent Care Center in Benin. Data were collected through face-to-face interview between the interviewer and the interviewee in addition to ASSIST-WHO, Family Assessment Device and Parental Acceptance and Rejection Scale. Results: The average age was $16.1 \pm 1.1$ years, ranging from 11 to 18 years. Sex ratio M/F was 22.4. School dropout rate was $76.9 \%$. Orphans represented $53.9 \%$. The proportion of juvenile offenders coming from broken families was $\mathbf{3 0 . 8 \%}$. Theft $(46.2 \%)$ and rape $(19.7 \%)$ were the main offenses committed. $99.1 \%$ had no criminal records and the judge requested for all of them a detention warrant. Psychoactive substance consumption records $(46.2 \%)$ were found, including: alcohol $(46.2 \%)$, tobacco $(23.9 \%)$, and cannabis $(10.3 \%)$. They felt maternal and paternal absence respectively in $48.7 \%$ and $44.4 \%$ cases and pleaded guilty in $\mathbf{7 1 . 8 \%}$. Pleading guilty was a resilience factor on which the counseling would have to rely for their rehabilitation and social reintegration.
\end{abstract}

"Corresponding author.

How to cite this paper: Djidonou, A., et al. (2016) Epidemiological and Psychosocial Profile of Juvenile Delinquency: Case Study of Delinquent Children and Adolescents under Court Order in Benin (2015). Open Journal of Psychiatry, 6, $135-142$. http://dx.doi.org/10.4236/ojpsych.2016.62016 
Keywords

Juvenile, Delinquency, Detention, Protection of the Adolescent, Benin

\section{Introduction}

Childhood and adolescence are stages when externalization and risk behaviors are common [1]. The child's externalized behavioral disorders are associated with agitation, impulsivity, aggressiveness or disobedience [2]. Most of these conducts are in the form of violence or aggressiveness towards others or themselves. One of the dreaded developments of these disorders is delinquency [3].

According to a survey conducted in France in 1997-1998, 7.8\% of young people between 12 and 19 years were injured or beaten at least once during the year [4]. In Switzerland, it is estimated that $7 \%$ of girls and 20\% of boys aged 15 to 20 years hit or beat someone, and that $21 \%$ of boys and $10 \%$ of girls caused damage to or willingly destroyed something during the year preceding the survey [5]. In the USA [6], two teenagers of 17 and 18 years have killed on 20th April 1998, 17 students and a teacher, harmed 23 other people in their university before committing suicide. Deficiencies or dysfunctions within the family, alongside their effects such as lack of affection, are some of the factors explaining the occurrence of violent behaviors from these children and adolescents. Moreover, different contextual factors mainly in connection with the family or the psychosocial environment are associated with the risk of conduct disorder with children and adolescents. Also, the affiliation to a gang at this tender age encourages teenagers to commit offenses.

The number of juvenile detainees charged in Benin increased from 64 in 2005 to 154 in 2009 representing an increase of $250 \%$. The absence of data which can explain this demographic explosion of children and adolescents in detention justifies the interest in this study.

\section{Methods of Study}

It was a cross-sectional and descriptive study, with prospective data collection from $6^{\text {th }}$ May 2015 to $10^{\text {th }}$ September 2015. The population under study concerned all juveniles detained in the civil prisons of Parakou, Kandi, Natitingou, Lokossa, Porto-Novo, Cotonou, Ouidah, Abomey, Abomey-Calavi and those under judicial injunction at Agblangandan Juvenile Protection Center. The inclusion criteria were: All juveniles in detention in one of the civil prisons (CP) concerned, aged from 11 to 18 years, able to respond to questions and present at the time of this study. Juveniles who did not give their informed consent to participate in the study were excluded. Sampling technique consisted in a comprehensive census followed by a consecutive recruitment of juveniles from CP in Benin who met the inclusion criteria. The total number of juveniles in the $\mathrm{CP}$ in addition to that of Agblangandan Juvenile Detention Center made up the size of the study sample comprising 117 juveniles. The dependent variable in the study was juvenile delinquency. "Any individual having violated a legal jurisdiction leading to legal proceeding" was considered as an offender [7]. The independent variables were represented by: socio-demographic factors (age, sex, ethnicity, education level, siblings), individual factors(parent-child relationship, couple relationship, family functioning, child's protection factors, the degree of severity of the child's behavioral disorder), behavioral addiction (use of psychoactive substances), judicial characteristics (detention warrant, relationship with the victim, criminal record, nature of the offense), socio-economic characteristics; monthly income (pocket money), resilience and resilience factors (psycho-emotional experience of the court ruling, closeness with the numinous and closeness with his people (visit). Data collection technique was a personal well-structured interview through a questionnaire including: Alcohol, Smoking and Substance Involvement Screening Test (ASSIST) [8] [9] to determine the score of psychoactive substance consumption in view of grouping in: No intervention "score between 0 - 3", Brief intervention "Score between 4 - 26", More intensive treatment: "score $\geq 27$ ", Parental Acceptance and Rejection scale [10] to assess the perception of the respondents concerning parental acceptation or rejection, Family Assessment Device or Epstein family functioning scale [11] [12]. Data collection procedures were in compliance with the ethical principles contained in the World Medical Association's Declaration of Helsinki [13].

Data processing and analysis were conducted using Epi info software version 7. The qualitative variables were expressed in frequency with $95 \%$ confidence interval. The comparison of frequencies was made using 
Chi-square test of Karl Pearson or that of Fischer depending on the case with a statistical significance threshold for $p$ less than $5 \%$.

\section{Results}

\subsection{Socio-Demographic Characteristics of Respondents}

The prevalence of male juveniles was 112/117 (95.7\%) with a sex-ratio H/F of 22.4. The average age was $16.1 \pm$ 1.1 years with age ranging from 11 to 18 years. The proportion of 17 years juveniles was $43.6 \%$. The prevalence of elders, $2^{\text {nd }}, 3^{\text {rd }}, 4^{\text {th }}, 5^{\text {th }}, 6^{\text {th }}$, and last born of the siblings was respectively; $28 / 117(23.9 \%), 20 / 117(17.1 \%)$, 28/117 (23.9\%), 18/117 (15.4\%), 15/117 (12.8\%), 1/117 (0.9\%) and 7/117 (6\%). The types of original family were: monogamous 13/117 (11.1\%) polygamous, 23/117 (19.7\%), broken 36/117 (30.8\%), united 18/117 (15.4\%), stepfamily 12/117 (10.3\%), broken polygamous $14 / 117$ (12\%) and single-parent 1/117 (0.9\%). Those whose parents were still alive were 54/117 (46.2\%), the rest was fatherless 29/117 (24.8\%), motherless 20/117 (17.1\%) or orphan of both parents 14/117 (12\%). The rate of school dropout was $76.9 \%$. In this category, school children (class 1 to class 6 ) were $41.0 \%$. Among the 90 school dropouts in detention, 76 (84.4\%) attended public institutions against 14 (15.6\%) who attended private institutions. They received 0 Cfa/day (19.8\%) or 200 $\mathrm{Cfa} /$ day $(18.1 \%)$ as pocket money for their petty expenses.

\subsection{Socio-Anthropological Characteristics}

3.2.1. Parents Attitudes toward the Child (Rohner and Khaleque Parental Acceptance and Rejection) Mothers showed affection to Delinquent Children and Adolescent Under Court Order (DCAUCO) in 42.7\% cases; fathers showing affection represented $27.4 \%$. Hostility/aggression from the father and the mother was recorded respectively in $48.7 \%$ and $44.4 \%$ of cases. Table 1 below presents the distribution of DCAUCO based on parental attitudes toward them.

\subsubsection{Family Functioning (Mc Master Model)}

Table 2 below presents the distribution of DCAUCO in Benin based on family functioning in $2015(\mathrm{n}=117)$.

\subsection{Behavioral and Psychological Characteristics}

\subsubsection{First Sexual Intercourse}

The first sexual intercourses were experienced at 18 years (1.5\%), 16 years (14.9\%), 15 years (26.9\%), 14 years (13.7\%), 10 years (6\%), and 8 years (1.5\%). The sexual partner was not specified in $51.3 \%$ of cases. When they were specified, the DCAUCO stated: girls in the neighborhood (12\%), cotenant (10.3\%), girlfriend (8.5\%), housemaid (6\%), classmate (4.3\%), and inbred sister (2.3\%).

\subsubsection{Inappropriate Behavior}

The beginning of behavioral disorders prior to detention was not indicated by 51.3\% of DCAUCO. They oc-

Table 1. Distribution of respondents based on parental attitudes toward DCAUCO in Benin in the year $2015(\mathrm{n}=117)$.

\begin{tabular}{|c|c|c|c|c|}
\hline & \multicolumn{2}{|c|}{ Number } & \multicolumn{2}{|c|}{ Percentages (\%) } \\
\hline & Yes & No & Yes & No \\
\hline Fatherly Warmth-Affection & 32 & 85 & 27.4 & 72.6 \\
\hline Motherly Warmth-Affection & 50 & 67 & 42.7 & 57.3 \\
\hline Motherly Hostility-Aggression & 57 & 60 & 48.7 & 51.3 \\
\hline Motherly Hostility-Aggression & 52 & 65 & 44.4 & 55.6 \\
\hline Fatherly Indifference-Negligence & 72 & 45 & 61.5 & 38.5 \\
\hline Motherly Indifference-Negligence & 53 & 64 & 45.3 & 54.7 \\
\hline Fatherly undifferentiated rejection & 65 & 52 & 55.6 & 44.4 \\
\hline Motherly undifferentiated rejection & 48 & 69 & 41.0 & 59.0 \\
\hline Fatherly general attitude & 41 & 76 & 35.0 & 65.0 \\
\hline Motherly general attitude & 65 & 52 & 55.6 & 44.4 \\
\hline
\end{tabular}


curred after 10 years for $41.8 \%$ of the respondents and before the age of 10 years for $7.7 \%$. Ritual ceremonies were conducted for $31.6 \%$ of DCAUCO, however in $86.5 \%$ of cases, the fact of not conducting these ritual ceremonies was not the consequence of subsequent behavioral disorder. DCAUCO recognize being responsible of maladaptive behaviors at various degrees: average (41\%), severe $(29.9 \%)$ and light $(29.1 \%)$ according to the DSM. These maladaptive practices were: burglary (41.9\%), rape (15.4\%), fighting (11.1\%), act of libel (10.3\%), use of a firearm under the influence of anger (6.8\%), stubbornness (5.1\%).

\subsubsection{Addictive Behavior}

The use of drug by DCAUCO was $46.2 \%$ for alcohol, $23.9 \%$ for tobacco and $10.3 \%$ for cannabis with need for intensive intervention concerning $3.4 \%$ consumers for each of the substances.

\subsection{Judicial Characteristics}

Table 3 below presents the distribution of DCAUCO based on criminal qualification of the offense, relationship with the victim, request for detention warrant and state of criminal record.

Table 2. Distribution of DCAUCO in Benin based on family functioning in $2015(\mathrm{n}=117)$.

\begin{tabular}{cccccccccc}
\hline & \multicolumn{4}{c}{ Number } & \multicolumn{4}{c}{ Percentages (\%) } \\
\hline & Excel $^{*}$ & Good $^{* *}$ & Poor $^{* * *}$ & Bad $^{* \mathbf{V}}$ & Excel & Good & Poor & Bad \\
\hline Problems resolution & 11 & 29 & 49 & 28 & 9.4 & 24.8 & 41.9 & 23.9 \\
Family communication & 13 & 24 & 49 & 31 & 11.1 & 20.5 & 41.9 & 26.5 \\
Assignment of roles & 11 & 26 & 49 & 31 & 9.4 & 22.2 & 41.9 & 26.5 \\
Emotional expression & 10 & 21 & 41 & 45 & 8.5 & 17.9 & 35.0 & 38.5 \\
Collective commitment & 9 & 19 & 36 & 53 & 7.7 & 16.2 & 30.8 & 45.3 \\
Monitoring behaviors & 11 & 25 & 41 & 40 & 9.4 & 21.4 & 35.0 & 32.2 \\
General family functioning & 14 & 34 & 48 & 21 & 12.0 & 29.1 & 41.0 & $17 ; 9$ \\
\hline
\end{tabular}

Excel $^{*}=$ Excellent; Poor $^{* * *}=$ Poor; Good ${ }^{* *}=$ Good; Bad $^{* \mathbf{v}}=$ Bad.

Table 3. Distribution of DCAUCO based on qualification of the offense, relationship with the victim, request for detention warrant and state of criminal record in Benin in $2015(n=117)$.

\begin{tabular}{|c|c|c|}
\hline & Number & Percentage (\%) \\
\hline \multicolumn{3}{|c|}{ Criminal qualification of the offense } \\
\hline Rape & 23 & 19.7 \\
\hline Manslaughter & 8 & 6.8 \\
\hline Theft & 54 & 46.2 \\
\hline Assassination/murder & 16 & 13.7 \\
\hline IGA $^{*}$ & 6 & 5.1 \\
\hline Poisoning & 1 & 0.9 \\
\hline Cyber crime & 9 & 7.7 \\
\hline \multicolumn{3}{|c|}{ Relationship with the victim } \\
\hline $1^{\text {st }}$ degree parent & 9 & 7.9 \\
\hline Family & 29 & 25.4 \\
\hline Unknown & 79 & 69.3 \\
\hline \multicolumn{3}{|c|}{ Request for detention warrant } \\
\hline Yes & 117 & 100.0 \\
\hline \multicolumn{3}{|c|}{ State of criminal record (staff) } \\
\hline Repeat offender & 1 & 0.9 \\
\hline Clean & 116 & 99.1 \\
\hline Total & 117 & 100.0 \\
\hline
\end{tabular}

IGA*; Intentional Grievous Assaults. 


\subsection{Resilience and Resilience Factors}

\section{- Resource persons}

Out of the 117 respondents, 39.3\% (46/117) stated that their mom was dearest to them, and then follows their friend $25.6 \%$ (30/117). The father accounted for only 17.9\% (21/117). The brothers and sisters were less dear, respectively $6.8 \%$ and $4.3 \%$.

\section{- Experience of the court ruling}

The proportion of DCAUCO who pleaded guilty was 71.8\%; those who pleaded not guilty were $17.1 \%$ whilst

$11.1 \%$ were without notice.

\section{- Closeness to numinous}

With regard to faith system, $72.6 \%$ of DCAUCO practise a religion within the prison, $10.3 \%$ had become fervent, $11.1 \%$ had a syncretistic practice and $6 \%$ had no religious practice.

\section{- Openness to external world (visit)}

Out of the 117 DCAUCO in the study, $76.9 \%$ had people visiting them in prison based on the distribution in Table 4 below.

\section{Discussion}

\subsection{Socio-Demographic Characteristics of DCAUCO in Benin}

In the study, the average age of respondents was $16.1 \pm 1.1$ years ranging from 11 to 18 years. The prevalence of male juveniles was $95.7 \%$ with a sex-ratio H/F of 22.4. Those who were 17 years (43.6\%) were more represented. This result is the same as the one recorded by Zimmermann et al. [14], in a study on adolescent repeat offenders (seven arrests in average) who indicated the average age to be 16.1 years. Similarly, Raymond et al. [15], in 2002 estimated at 16.2 years, the average age of adolescent offenders in the Canadian criminal justice

Table 4. Distribution of DCAUCO in Benin in 2015 ( $n=117)$ based on of their closeness to the external world (visit).

\begin{tabular}{|c|c|c|}
\hline & Number & Percentage (\%) \\
\hline \multicolumn{3}{|l|}{ Visit } \\
\hline Often & 18 & 15.4 \\
\hline Sometimes & 33 & 28.2 \\
\hline Rare & 39 & 33.3 \\
\hline Never & 27 & 23.1 \\
\hline Total & 117 & 100.0 \\
\hline \multicolumn{3}{|l|}{ Father } \\
\hline Yes & 39 & 43.3 \\
\hline No & 51 & 56.7 \\
\hline Total & 90 & 100.0 \\
\hline \multicolumn{3}{|l|}{ Mother } \\
\hline Yes & 52 & 57.8 \\
\hline No & 38 & 42.2 \\
\hline Total & 90 & 100.0 \\
\hline \multicolumn{3}{|l|}{ Guardians } \\
\hline Yes & 2 & 2.2 \\
\hline No & 88 & 97.8 \\
\hline Total & 90 & 100.0 \\
\hline \multicolumn{3}{|c|}{ Other Visitors } \\
\hline Yes & 50 & 55.6 \\
\hline No & 40 & 44.4 \\
\hline Total & 90 & 100.0 \\
\hline
\end{tabular}


system.

On the whole DCAUCO in Benin (2015), 12.0\% were orphans of both parents and 23.9\% were in $1^{\text {st }}$ or $3^{\text {rd }}$ position following childbirth. Children from broken families accounted for $30.8 \%$, and $0.9 \%$ were from single-parent families. The study of Raymond et al. specifies that the time of committing the offense leading to their current sentence, $42 \%$ of the adolescents were living in a single-parent family headed by the mother. This leads to concluding that in terms of social determinants of delinquency, the presence of both parents in ensuring the education of the child could be a protective factor against juvenile delinquency.

The rate of school dropout was 76.9\%. Juvenile offenders in Benin CP dropped out from school from class 1 to class 6 (41.0\%). This "dropout was associated with personal, familial or educational difficulties which, cumulatively foster the emergence of accession or success-related-issues in school” [16].

Out of the 90 detainees who were in school, 76 (84.4\%) came mainly from public institutions against 14 (15.6\%) from private institutions. The low level of education and other cultural causes would favor the adoption of criminal behaviors among these juveniles. Delinquency is closely associated with education and material insecurity.

\subsection{Socio-Anthropological Characteristics}

A high proportion of indifference and act of negligence (61.5\%) was noted on the part of the fathers (see Table 1). Concerning the undifferentiated rejection, fathers are more prevalent. In at least one DCAUCO out of three (41.9\%), there was "poor" communication (see Table 2). Moreover, it was deemed to be "good" in 20.5\% of cases. This would be the source of "bad" assignment of roles (26.5\%). Only 9.4\% of these DCAUCO claimed "good" assignment of roles. Likewise, emotional expression was "poor" in $38.5 \%$ of cases and was deemed to be "good" in less than one third DCAUCO (17.9\%). Poor communication and deficient assignment of parental roles are the root causes of a poor collective commitment among DCAUCO. It is assumed that early bond relationships are important because the mental mechanism which regulates the expression of the individual genotype is inherently linked to the relations established with the first care providers [17]. According to Ethier et al. [18], there are dramatic consequences related to the fact of having been neglected during childhood and persistence of these difficulties with time, as well as a high prevalence of the difficulties associated with socio-emotional adjustment in adolescence. In fact, the collective commitment was "bad" for almost half of the respondents (45.3\%), "poor” in 30.8\% of cases; "good” in 16.2\% of cases and "excellent” in only 7.7\%. This contributed to "poor" or "bad" family functioning in more than half of the respondents (58.9\%). Only 29.1\% stated that their family functioning was "good”. These results are the reflection of our society which gives very little consideration to the views of children, while investing enormously in elders and last born.

\subsection{Psychological and Behavioral Characteristics}

\section{- Sexual behaviors}

Less than one third of DCAUCO (26.9\%) was 15 years before the $1^{\text {st }}$ sexual intercourse; $1.5 \%$ of them were only 8 years. For $51.3 \%$ the sexual partner is not specified. In $12 \%$ cases it is a girl in the neighborhood, whilst the housemaid represented (6\%) and the inbred sister (2.3\%). As soon as the parent is no longer accessible to the child to support him in terms of sexual ethics, the child is sexually initiated by the neighboring or the inbred sister. The boundary is then quickly crossed. In a study on juvenile sex offenders, Rabaux [19] reported that "one quarter of people suspected of committing sexual violence is a minor”. These juveniles in quest of strong sensations and inclined to delinquency, adopt socially unfriendly behaviors. They received no sex education which is a taboo subject in our societies and often they seek to copy stereotypes from elsewhere, especially from pornographic visuals. Early sex, clandestine abortions and the risk of HIV-AIDS undermine the health of this subpopulation [20].

\section{- Inappropriate behavior}

Before being subjected to the law, these juveniles were committing: burglary and theft (41.9\%), rape (15.4), fighting (11.1\%). When the extinction of these behaviors is not achieved, they determine later the causes of prosecution within the framework of social defense. Early dropout from school, aggressiveness, peers pressure and the risk-taking environment have a negative impact on the internalization of the patterns of social good behavior among these juveniles. More than one third of the DCAUCO (41\%) had mild behavioral disorders and for $51.3 \%$, the age of the starting of these disorders is unknown. In the social imagination, there is a link be- 
tween behavioral disorders and traditional rituals such as baptism and healing. Ritual ceremonies were conducted for $31.6 \%$ of DCAUCO involved in the study. However, subsequent behavioral disorder was not attributable to the absence of ceremony at birth (86.5\%). Addiction to alcohol (46.2\%), tobacco (23.9\%), and cannabis $(10.3 \%)$ by the DCAUCO reveal that the detention of juvenile offenders as correctional measure in the current state is to be reconsidered for a real protection of these juvenile offenders.

\subsection{Judicial Characteristics}

Theft (46.2\%), rape (19.7\%), assassination/murder (13.7\%), intentional grievous assaults (5.1\%), cyber crime (7.7\%) and manslaughter (6.8\%) were the main offenses committed by the DCAUCO (see Table 3). In 69.3\% of cases, they had no relationship with their victims who were unknown to them. All (100\%) were served with a detention warrant whilst 99.1\% had clean criminal record. In a study conducted in Abidjan by Yapo Ette et al. [21], theft in meeting represented $61.2 \%$ of offenses leading to interim custody.

\subsection{Resilience and Resilience Factors}

Resource persons for the DCAUCO in the study were; mother 39.3\% and friend(s) 19.7\%. The mother was the confidante of the detained adolescents, followed by friends. The father accounted for $17.9 \%$. The negative influence of peers, financial problems and/or the difficulties to communicate with the parents did not allow them to express their emotional and material needs without infringing social standards. Consequently, the resolution of the problems was "poor" in at least one third (41.9\%) of the DCAUCO.

The prevalence of juveniles who received visitors in prison was to 76.9\% (cf. Table 4). Mothers visited more often their children (57.8\%). These results show that the tenderness from the mothers to their children can be a resilience factor to be considered in saving juvenile offenders. To this effect, both the father and mother are vital. The analysis of various cases revealed that one factor that may cause problematic behavior appears when children fail in not only being accepted effectively by their family but also occupying indubitable place/position within the family as a child. 71.8\% of DCAUCO who pleaded guilty have an assurance of awareness and a possibility of returning and playing an effective role within the society.

\section{Conclusion}

Juvenile delinquency has now become alarmingly common in our environment. It has also become more violent and particularly concerns juveniles. A number of risk factors, principally family dysfunction contributes to this scourge. In our study, the judicial qualifications of offenses commit namely theft, rape, murder, assassination, poisoning, drug abuse, and cyber crimeraise fear of delaying our country's development. But the fact is that most plead guilty is a resilience factor to be wisely utilized by remedial actions aimed at children and adolescents protection for better social roles assignment.

\section{Conflict of Interest}

None.

\section{References}

[1] Fortin, L. (2002) Violence et problèmes de comportement. Enquête sociale et de santé auprès des enfants et des adolescents québécois 1999, 451-470.

[2] Roskam, I., Kinoo, P. and Nassogne, M.C. (2007) L’enfant avec troubles externalisés du comportement: Approche épigénétiqueet développementale. Neuropsychiatrie de l'Enfance et de l'Adolescence, 55, 204-213. http://dx.doi.org/10.1016/j.neurenf.2007.01.005

[3] Robert, P. and Pottier, M.L. (1997) “On ne se sent plus en sécurité”: Délinquance et insécurité une enquête sur deux décennies. Revue française de science politique, 47, 707-740.

[4] Arènes, J., Janvrin, M.-P. and Beaudier, F. (1998) Baromètre santé jeunes 97/98. Vanves, France, Éditions CFES.

[5] Michaud, P.A. and Narring, F. (1993) Recherche sur la santé et le style de vie des adolescents romands de 15 à 20 ans. Institut universitaire de médecine sociale et préventive, Lausanne.

[6] Elodie, S. (2008) Le port d'armes aux Etats Unis. Docs. School Publications. 
[7] Gouba, Y. (2012) Déficience intellectuelle légère et expertises psycho-judiciaires: Le cas des délinquants juvéniles. Doctoral Dissertation, University of Geneva.

[8] Humeniuk, R., Henry-Edwards, S., Ali, R., Poznyak, V. and Monteiro, M.G. (2010) The Alcohol, Smoking and Substance Involvement Screening Test (ASSIST): Manual for Use in Primary Care.

[9] Johnson, J.A., Bembry, W., Peterson, J., Lee, A. and Seale, J.P. (2015) Validation of the ASSIST for Detecting Unhealthy Alcohol Use and Alcohol Use Disorders in Urgent Care Patients. Clinical and Experimental Research, Alcoholism. http://dx.doi.org/10.1111/acer.12733

[10] Malik, F. (2010) Determinants of Child Abuse in Pakistani Families: Parental Acceptance-Rejection and Demographic Variables. International Journal of Business and Social Science, 1, 67-80.

[11] Epstein, N.B., Baldwin, L.M. and Bishop, D.S. (1983) The McMaster Family Assessment Device. Journal of Marital and Family Therapy, 9, 171-180. http://dx.doi.org/10.1111/j.1752-0606.1983.tb01497.x

[12] Miller, I.W., Epstein, N.B., Bishop, D.S. and Keitner, G.I. (1985) The McMaster Family Assessment Device: Reliability and Validity. Journal of Marital and Family Therapy, 11, 345-356. http://dx.doi.org/10.1111/j.1752-0606.1985.tb00028.x

[13] World Medical Association (2015) WMA Declaration of Helsinki-Ethical Principles for Medical Research Involving Human Subjects. Adopted by the 18th WMA General Assembly, Helsinki, Finland, June 1964 and Amended (Latest) by the 64th WMA General Assembly, Fortaleza, Brazil, October 2013.

[14] Zimmermann, G., Rossier, V., Bernard, M., Cerchia, F. and Quartier, V. (2005) Sévérité de la consommation d’alcool et de cannabis chez des adolescents tout-venant et délinquants. Neuropsychiatrie de l'enfance et de l'adolescence, 53, 447-452. http://dx.doi.org/10.1016/j.neurenf.2005.10.002

[15] Corrado, R.R. and Cohen, I.M. (2002) Profil de besoins des jeunes délinquants autochtones incarcérés pour crimes graves ou de violence. FORUM-Recherche sur l'actualité correctionnelle, 14, 24-29.

[16] Blaya, C. and Fortin, L. (2011) Les élèves français et québécois à risque de décrochage scolaire: Comparaison entre les facteurs de risque personnels, familiaux et scolaires. L'orientation scolaire et professionnelle, (40/1), 2011. http://osp.revues.org/2988

[17] Fonagy, P. (2001) Développement de la psychopathologie de l’enfance à l’âge adulte: Le mystérieux déploiement des troubles dans le temps. La psychiatrie de l'enfant, 44, 333-369. http://dx.doi.org/10.3917/psye.442.0333

[18] Ethier, L.S. and Milot, T. (2009) Effet de la durée, de l’âge d'exposition à la négligence parentale et de la comorbidité sur le développement socioémotionnel à l'adolescence. Neuropsychiatrie de l'enfance et de l'adolescence, 57, 136145. http://dx.doi.org/10.1016/j.neurenf.2008.12.004

[19] Rabaux, J. (2007) Les mineurs délinquants sexuels. Journal du droit des jeunes, 5, 15-21. http://dx.doi.org/10.3917/jdj.265.0015

[20] Ngo Mayack, J. (2015) Politique de planification familiale au Cameroun: Quelle place pour les jeunes? Autrepart, 70, 57-71. http://dx.doi.org/10.3917/autr.070.0057

[21] Yapo Ette, H., Djodjo, M., Botti, K., Diakite, A., Kouyate, M. and Ebouat, M.E. (2009) Le Centre d’Observation des Mineurs d’Abidjan: Présentation-Fonctionnement-Profil épidémiologique et sanitaire des mineurs. Journal de médecine légale droit médical, 52, 3-12. 